\title{
The Correlation between Estimated Glomerular Filtration Rate and Parathyroid Hormone Levels in Predialysis-chronic Kidney Disease Adult Patients at Sanglah General Hospital, Bali, Indonesia
}

\author{
Sianny Herawati ${ }^{1 *}$ (D), Yenny Kandarini ${ }^{2}$ (D) I Putu Yuda Prabawa ${ }^{1}$ (D) \\ ${ }^{1}$ Department of Clinical Pathology, Faculty of Medicine, Universitas Udayana, Sanglah General Hospital, Bali, Indonesia; \\ ${ }^{2}$ Department of Internal Medicine, Faculty of Medicine, Universitas Udayana, Sanglah General Hospital, Bali, Indonesia
}

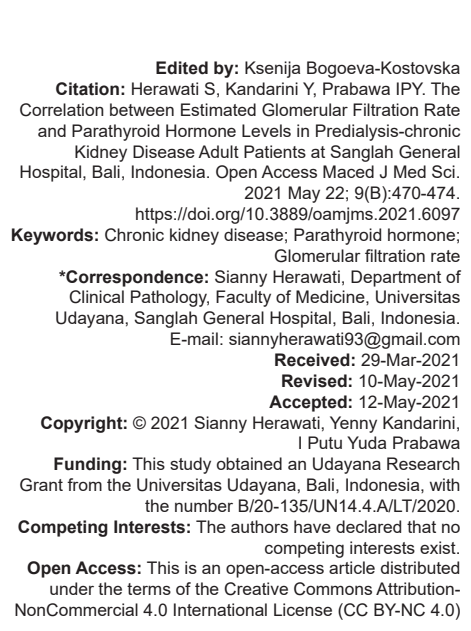

\begin{abstract}
s
BACKGROUND: Chronic kidney disease (CKD) is a structural or functional kidney disease for more than 3 months. In predialysis CKD patients, the serum parathyroid hormone levels increase progressively since the early stages of the disease to maintain phosphate homeostasis. Glomerular filtration rate (GFR) has been widely accepted to assess renal function. The GFR assessment is used to determine the CKD stadium.

AIM: This study aims to analyze the correlation between GFR and parathyroid hormone levels in predialysis CKD patients undergoing treatment at Sanglah General Hospital Denpasar.

METHODS: A cross-sectional observational study was conducted among predialysis CKD patients undergoing treatment at Sanglah General Hospital Denpasar who met the inclusion and exclusion criteria. The inclusion criteria were adult patients ( $\geq 18$ years) who were accepting to participate in the study. Exclusion criteria were patients with predialysis CKD after thyroidectomy and/or parathyroidectomy and liver disease. The parathyroid hormone levels, blood urea nitrogen, creatinine, and GFR were examined and analyzed by SPSS version 17 for Windows.

RESULTS: A total of 77 patients with predialysis CKD in this study obtained a median of e-GFR of 21.09 $(4.72-75.80) \mathrm{mL} / \mathrm{min} / 1.73 \mathrm{~m}^{2}$. The median level of parathyroid hormone was $82.07 \mathrm{pg} / \mathrm{mL}(15.83-716.60 \mathrm{pg} / \mathrm{mL})$. Spearman's correlation analysis results obtained a strong and significant negative correlation between the e-GFR value and parathyroid hormone levels $(r=-0.540 ; p=0.000)$.

CONCLUSION: The parathyroid hormone levels assessment could be used as a recommendation in evaluating the CKD progressivity among predialysis adult patients at Sanglah General Hospital, Bali, Indonesia, due to the strong
\end{abstract} significant correlation.

\section{Introduction}

Chronic kidney disease (CKD) is currently increasing and has become a serious health problem [1]. The global prevalence for CKD was $13.4 \%$, with $10.6 \%$ at CKD stages 3-5 [2]. Global Burden of Disease 2015 states that kidney disease is the $12^{\text {th }}$ cause of death globally and is projected to be the $5^{\text {th }}$ cause of death in 2040 [3]. Over the past 10 years, the death rate due to CKD has increased by $31.7 \%$ [4]. According to the 2018 Basic Health Research (RISKESDAS) data, the population aged $\geq 15$ years diagnosed with chronic kidney failure in Indonesia is $0.38 \%$ and for Bali Province, the prevalence of CKD is $0.44 \%$, with the proportion of CKD patients undergoing hemodialysis is $37.04 \%$ [5]. Data at the Sanglah Denpasar Central General Hospital (RSUP) in 2018, CKD patients ranked first out of the top 10 cases of all patients visiting the internal medicine polyclinic. In May 2019, the total number of CKD patient visits was $25 \%$ of the total patients who visited the internal medicine polyclinic [6].
Secondary hyperparathyroidism is a complication that often occurs in patients with CKD, which is a mineral and bone metabolism disorder known as mineral and bone disorders in CKD (MBD-CKD) [7]. This disorder's pathogenesis is characterized by increased secretion of parathyroid hormone and hyperplasia of the parathyroid glands in response to low phosphate and serum 1,25-dihydroxy Vitamin D retention [7]. Secondary hyperparathyroidism will cause vascular calcification associated with increased cardiovascular disease mortality [8], [9], [10]. The prevalence and burden of cardiovascular complications increase with decreasing kidney function. The risk of death from cardiovascular disease is 8 times, 2 times greater in patients with stage CKD G5 A3 (estimated glomerular filtration rate $[e G F R]<15 \mathrm{ml} / \mathrm{min} / 1.73 \mathrm{~m}^{2}$ and urine albumin to creatinine ratio $>300 \mathrm{mg} / \mathrm{g}$ ) than in populations without kidney disease [10].

In predialysis CKD serum, parathyroid hormone levels increase progressively from the early stages of the disease to maintain phosphate homeostasis [11]. Nearly $20 \%$ of patients with eGFR $>60 \mathrm{~mL} / \mathrm{min} / 1.73 \mathrm{~m}^{2}$ experienced increased parathyroid hormone levels 
and increased when kidney function deteriorated [12]. The incidence of secondary hyperparathyroidism was reported to increase according to the increase in the CKD stage, namely: $40 \%$ at Stage $3,70 \%$ at Stage 4 , and $>80 \%$ at Stage 5 [8]. Research by de Boer et al. found that parathyroid hormone levels have a negative significant correlation with e-GFR $(r=-0.48$; $p<0.0001$ ) [13]. However, a previous study by de Boer et al. did not mention the etiology diagnosis regarding the CKD-patients in evaluating the parathyroid level. In addition, a multicenter cohort study in predialysis CKD patients found that a persistent increase in serum parathyroid hormone was associated with a worse prognosis independent of baseline serum parathyroid hormone and phosphate values [12].

Kidney Disease Improving Global Outcomes (KDIGO) 2017 recommends routine parathyroid hormone, calcium, and phosphate checks on CKD patients starting from stage 3-5 to prevent or delay complications related to CKD [14]. KDIGO also suggests that MBD-PGK management should be based on serial measurements of parathyroid hormone serum and the tendency to persistently increase parathyroid hormone levels above the upper limit of normal value has more clinical significance than just one measurement [15]. Based on those mentioned above, this study aims to analyze the correlation between e-GFR and parathyroid hormone levels in predialysis CKD patients undergoing treatment at Sanglah General Hospital.

\section{Methods}

\section{Sample criteria}

A cross-sectional observational study has been conducted among 77 CKD patients at the Nephrology Polyclinic and inpatient rooms of the Sanglah General Hospital Denpasar from July 2020 to September 2020. The inclusion criteria were patients who had been diagnosed with CKD and have not undergone dialysis. Male and female aged $\geq 18$ years who are participating in this study had been signed the informed consent. In comparison, the exclusion criteria in this study included patients with a history of post-thyroidectomy and/ or parathyroidectomy as well as a history of chronic liver disease. The sampling technique was carried out consecutively. The etiology of CKD mention in this study was diabetic nephropathy, chronic pyelonephritis, obstructive nephropathy, polycystic kidney, gout nephropathy, and nephrosclerosis.

\section{Variables assessed}

e-GFR is GFR measured numerically using the CKD Epidemiology Collaboration (CKD-EPI) formula.
e-GFR is the GFR measured using the CKD-EPI formula, which has units of $\mathrm{ml} / \mathrm{min} / 1.73 \mathrm{~m}^{2}$. Parathyroid hormone level is the parathyroid hormone level of the predialysis CKD patient who was checked using the Cobas e601 Roche Diagnostics, GmbH, Germany, using the Electrochemiluminescence immunoassay method. The sample used was venous blood serum using a tube using a $3 \mathrm{ml}$ red cap tube. The unit used in the measurement scale in this study is $\mathrm{pg} / \mathrm{ml}$. Meanwhile, what is meant by patients with CKD are patients who have been diagnosed with CKD according to the KDIGO criteria upheld by a doctor in the Internal Medicine department and have never undergone dialysis based on medical record records. Other clinical data assessed in this study included proteinuria (mg/dL), status of diabetes mellitus, blood pressure $(\mathrm{mmHg})$, and body mass index $(\mathrm{BMI})\left(\mathrm{kg} / \mathrm{m}^{2}\right)$.

\section{Data analysis}

All data obtained in this study were analyzed descriptively. The results will be presented in the form of mean \pm standard deviation if the data are normally distributed and in the median (minimummaximum) form if the data are not normally distributed. Respondent characteristic data are displayed in the form of absolute numbers and percentages. The data normality test used Kolmogorov-Smirnov and the correlation between GFR and intact PTH levels used the Spearman correlation. Data were analyzed using SPSS version 17 for Windows.

\section{Results}

About 77 patients with predialysis CKD followed this study at the Sanglah Hospital Nephrology polyclinic, who met the inclusion and exclusion criteria. The characteristics of CKD patients who are research subjects are shown in Table 1. In this study, the median age of the patients was 61 years. The youngest patient was 23 years old, while the oldest patient was 81 years old. The number of male patients is more than the number of female patients. The patient's median BMI was $22.9 \mathrm{~kg} / \mathrm{m}^{2}$, the lowest BMl was $16.3 \mathrm{~kg} / \mathrm{m}^{2}$, and the highest was $34.4 \mathrm{~kg} / \mathrm{m}^{2}$ (Table 1).

Based on the CKD stage according to KDIGO 2017, at Stage 2 it was $2.6 \%$, Stage 3a: 9.1\%, Stage 3b: $16.9 \%$, Stage 4: $28.6 \%$, and Stage 5: $42.9 \%$. Based on the etiological diagnosis, the patients were diabetic nephropathy $44.2 \%$, chronic pyelonephritis $31.2 \%$, obstructive nephropathy $18.9 \%$, nephrosclerosis $5.2 \%$, polycystic kidney, and uric acid nephropathy, respectively, $1.3 \%$ (Table 1 ). In addition, a total of 77 predialysis CKD patients had a median e-GFR (CKDEPI) value of $21.09(4.72-75.80) \mathrm{mL} / \mathrm{min} / 1.73 \mathrm{~m}^{2}$ 
Table 1: Baseline characteristic of respondents

\begin{tabular}{|c|c|c|}
\hline Characteristics & Percentage & Median (min-max) \\
\hline Age (years) & & $61(23.00-81.00)$ \\
\hline \multicolumn{3}{|l|}{ Gender } \\
\hline Male & $50(64.90)$ & \\
\hline Female & $27(35.10)$ & \\
\hline BMI $\left(\mathrm{kg} / \mathrm{m}^{2}\right)$ & & $22.9(16.30-34.40)$ \\
\hline \multicolumn{3}{|l|}{ CKD stage $\left(\mathrm{kg} / \mathrm{m}^{2}\right)$} \\
\hline Stadium $2(60-89)$ & $2(2.60)$ & \\
\hline Stadium 3a (45-59) & $7(9.10)$ & \\
\hline Stadium $3 b(30-44)$ & $13(16.90)$ & \\
\hline Stadium 4 (15-29) & $22(28.60)$ & \\
\hline Stadium $5(<15)$ & $33(42.90)$ & \\
\hline \multicolumn{3}{|l|}{ Etiology diagnosis } \\
\hline Diabetic nephropathy & $34(44.20)$ & \\
\hline Chronic pyelonephritis & $24(31.20)$ & \\
\hline Obstructive nephropathy & $13(16.90)$ & \\
\hline Polycystic kidney & $1(1.30)$ & \\
\hline Gout nephropathy & $1(1.30)$ & \\
\hline Nephrosclerosis & $4(5.20)$ & \\
\hline \multicolumn{3}{|l|}{ Predialysis assessment } \\
\hline e-GFR (CKD-EPI) $\left(\mathrm{mL} / \mathrm{min} / 1.73 \mathrm{~m}^{2}\right)$ & & $21.09(4.72-75.80)$ \\
\hline Parathyroid hormone $(\mathrm{pg} / \mathrm{mL})$ & & $82.07(15.83-716.60)$ \\
\hline \multicolumn{3}{|c|}{ Parathyroid hormone classification $(\mathrm{pg} / \mathrm{mL})$} \\
\hline Low $(<15)$ & $0(0.00)$ & \\
\hline Normal (15-65) & $30(38.96)$ & \\
\hline High (> 65) & $47(61.04)$ & \\
\hline BUN (mg/dL) & & $36.60(11.40-107.90)$ \\
\hline Serum creatinine $(\mathrm{mg} / \mathrm{dL})$ & & $2.94(0.96-10.30)$ \\
\hline \multicolumn{3}{|l|}{ Blood pressure $(\mathrm{mmHg})$} \\
\hline Systole & & $120(120-170)$ \\
\hline Diastole & & $80(80-90)$ \\
\hline \multicolumn{3}{|l|}{ Diabetes mellitus } \\
\hline Yes & $48(62.30)$ & \\
\hline No & $29(37.70)$ & \\
\hline Proteinuria $(\mathrm{mg} / \mathrm{dL})$ & & $100.00(0.00-600.00)$ \\
\hline
\end{tabular}

(Table 1). Besides, the median value of parathyroid hormone levels in predialysis CKD patients was 82.07 (15.83-716.60) pg/mL (Table 1). The distribution of parathyroid hormone levels in 77 patients was categorized into normal $(15-65 \mathrm{pg} / \mathrm{mL})$ in $30(38.96 \%)$ patients and high $(>65 \mathrm{pg} / \mathrm{mL})$ in $47(61.04 \%)$ patients. There were no low parathyroid hormone levels $<15 \mathrm{pg} / \mathrm{mL}$ in the study patients $(0.00 \%)$ (Table 1$)$.

Spearman correlation test was also conducted between the CKD stage and parathyroid hormone levels. There was a significant low-positive correlation between the CKD stage and parathyroid hormone levels $(r=0.362 ; p=0.000)$ in predialysis CKD patients (Table 2). However, a Spearman correlation test found a significant moderate negative correlation between e-GFR and parathyroid hormone levels $(r=-0.540$; $p=0.000$ ) in predialysis CKD patients (Table 2).

Table 2: Spearman correlation test of parathyroid hormone levels to the CKD stages and e-GFR levels in predialysis CKD patients

\begin{tabular}{lll}
\hline Variables & \multicolumn{2}{c}{ Parathyroid hormone levels $(\mathrm{pg} / \mathrm{mL})$} \\
\cline { 2 - 3 } & $\mathrm{r}$ & $\mathrm{p}$ \\
\hline CKD stages & 0.362 & $0.000^{*}$ \\
e-GFR $\left(\mathrm{mL} / \mathrm{min} / 1.73 \mathrm{~m}^{2}\right)$ & -0.540 & $0.000^{*}$ \\
\hline CKD: Chronic kidney disease, e-GFR: Estimation of glomerular filtration rate, ${ }^{*}$ Statistically significant if \\
p<0.001.
\end{tabular}

\section{Discussion}

CKD is a common condition that refers to a longterm loss of kidney function [16]. CKD in primary care is commonly asymptomatic, and the exact pathology underlying its development is often unknown (as no renal biopsy is usually performed) [16]. It is identified and defined by the presence of an abnormality of kidney structure or function (or both) present for at least 3 months by evaluating the GFR [17]. Several studies have shown that there was a relationship between GFR and parathyroid hormone levels in predialysisCKD where it could lead to the parathyroid hormone levels increase progressively from the early stages of the disease to maintain phosphate homeostasis and worsening the prognosis [18], [19], [20].

A significant negative correlation was found between the e-GFR value and parathyroid hormone levels in CKD predialysis patients at Sanglah General Hospital, Bali, Indonesia. Research Pala et al. found that $57.5 \%$ of their study patients had hyperparathyroidism with a significantly higher frequency of stage four CKD compared to third stage CKD $(47.1 \%$ third stage CKD, and $89.3 \%$ fourth stage CKD, $p<0.001$ ) [21]. A cross-sectional study involving 415 CKD patients in Spain received the median parathyroid hormone at stage three CKD of $86 \mathrm{pg} / \mathrm{mL}$ and $120 \mathrm{pg} / \mathrm{mL}$ at stage four CKD [22]. In addition, the previous studies by Levin et al. and Wei et al. stated that the prevalence of significantly increased parathyroid hormone levels occurs at eGFR $<50 \mathrm{ml} / \mathrm{min} / 1.73 \mathrm{~m}^{2}$ [8], [23]. Based on the eGFR group, it can be concluded that the median distribution of parathyroid hormone levels in the eGFR group Stages 2-5 shows a tendency to increase with decreasing eGFR values.

This study also suggests a significant lowpositive correlation between the CKD stage and parathyroid hormone levels. Several previous studies also showed a significant correlation between eGFR and parathyroid hormone levels, namely, de Boer et al. $(r=-0.48 ; p<0.0001)$ and Malawadi et al. $(r=-0.718$; $p<0.001)$ [13], [24]. An increase in parathyroid hormone is considered an early marker of MBD-CKD. Examination of parathyroid hormone levels in CKD is a significant predictor of cardiovascular morbidity and mortality, endothelial dysfunction, or systemic inflammation. KDIGO 2017 recommends performing routine parathyroid hormone examinations for CKD patients starting at Stage 3-5 to prevent or delay complications of BMD-CKD [10], [13], [24].

Based on the discussion above, the authors assume that early evaluation of parathyroid hormone evaluation, from the Stage 1, has a significant role in preventing the progressivity of CKD among predialysis adult patients as well as delaying the future complications. However, further study with bigger sample size, longitudinal study, and follow-up evaluation of parathyroid hormone are suggested to clarify the limitation of this study. 


\section{Conclusion}

The parathyroid hormone levels assessment could be used as a recommendation in evaluating the CKD progressivity among predialysis adult patients at Sanglah General Hospital, Bali, Indonesia, due to the strong significant correlation.

\section{Ethics Consideration}

Ethics approval has been received from the Ethics Committee, Faculty of Medicine, Universitas Udayana, Sanglah General Hospital, Bali, Indonesia with Number:1613/UN14.2.2.VII.14/LT/2020 prior to the study being conducted.

\section{Author Contribution}

All authors equally contributed to the study from the conceptual framework, data gathering, and data analysis until the publication of the study results.

\section{References}

1. Webster AC, Nagler EV, Morton RL, Masson P. Chronic kidney disease. Lancet. 2017;389(10075):1238-52. https://doi. org/10.1016/s0140-6736(16)32064-5

PMid:27887750

2. Hill NR, Fatoba ST, Oke JL, Hirst JA, O'Callaghan CA, Lasserson DS, et al. Global prevalence of chronic kidney disease-a systematic review and meta-analysis. PLoS One. 2016;11(7):e0158765. https://doi.org/10.1371/journal. pone. 0158765

PMid:27383068

3. Banerjee D, Jha V. Vitamin D and cardiovascular complications of CKD: What's next? Clin J Am Soc Nephrol. 2019;14(6):932-4. PMid:31064752

4. Neuen BL, Chadban SJ, Demaio AR, Johnson DW, Perkovic V. Chronic kidney disease and the global NCDs agenda. BMJ Glob Health. 2017;2(2):e000380. https://doi.org/10.1136/ bmjgh-2017-000380

PMid:29225940

5. Indonesia Ministry of Health. National Ministry of Health Reports 2018. Jakarta: National Institute of Health Research and Development; 2018. https://doi.org/10.25133/jpssv27n1.003

6. Sanglah General Hospital, Outpatient Installation Service Report for at Sanglah Hospital Denpasar During May 2019; 2019.

7. Kanai G, Fukagawa M. CKD-MBD (chronic kidney diseasemineral and bone disorder). Gene therapy for secondary hyperparathyroidism. Clin Calcium. 2010;20(7):1052-9. PMid:20585184

8. Wei Y, Lin J, Yang F, Li X, Hou Y, Lu R, et al. Risk factors associated with secondary hyperparathyroidism in patients with chronic kidney disease. Exp Ther Med. 2016;12(2):1206-12. PMid:27446345

9. Yuen NK,Ananthakrishnan S, Campbell MJ. Hyperparathyroidism of renal disease. Perm J. 2016;20(3):15-127. PMid:27479950

10. Bello AK, Alrukhaimi M, Ashuntantang GE, Basnet S, Rotter RC Douthat WG, et al. Complications of chronic kidney disease: Current state, knowledge gaps, and strategy for action. Kidney Int Suppl (2011). 2017;7(2):122-9. https://doi.org/10.1016/j. kisu.2017.07.007 PMid:30675426

11. Coen G, Ballanti P, Bonucci E, Calabria S, Costantini S, Ferrannini $\mathrm{M}$, et al. Renal osteodystrophy in predialysis and hemodialysis patients: Comparison of histologic patterns and diagnostic predictivity of intact PTH. Nephron. 2002;91(1):10311. https://doi.org/10.1159/000057611

PMid:12021526

12. Borrelli S, Chiodini P, de Nicola L, Minutolo R, Provenzano M, Garofalo C, et al. Prognosis and determinants of serum PTH changes over time in 1-5 CKD stage patients followed in tertiary care. PLoS One. 2018;13(8):e0202417. https://doi.org/10.1371/ journal.pone.0202417

PMid:30138402

13. de Boer IH, Gorodetskaya I, Young B, Hsu CY, Chertow GM The severity of secondary hyperparathyroidism in chronic renal insufficiency is GFR-dependent, race-dependent, and associated with cardiovascular disease. J Am Soc Nephrol. 2002;13(11):2762-9. https://doi.org/10.1097/01. asn.0000034202.91413.eb PMid:12397047

14. Erratum: Kidney disease: Improving global outcomes (KDIGO) CKD-MBD update work group. KDIGO 2017 clinical practice guideline update for the diagnosis, evaluation, prevention, and treatment of chronic kidney disease-mineral and bone disorder (CKD-MBD). Kidney Int Suppl. 2017;7:1-59. Kidney Int Suppl (2011). 2017;7(3):e1. https://doi.org/10.1016/j.kisu.2017.10.001 PMid:30681074

15. Kakuta $T$, Ishida M, Fukagawa M. Critical governance issue of parathyroid hormone assays and its selection in the management of chronic kidney disease mineral and bone disorders. Ther Apher Dial. 2018;22(3):220-8. https://doi. org/10.1111/1744-9987.12690 PMid:29781225

16. Chen TK, Knicely DH, Grams ME. Chronic kidney disease diagnosis and management:Areview. JAMA. 2019;322(13):1294304. https://doi.org/10.1001/jama.2019.14745 PMid:31573641

17. Delanaye P, Cavalier E. Staging chronic kidney disease and estimating glomerular filtration rate: An opinion paper about the new international recommendations. Clin Chem Lab Med. 2013;51(10):1911-7. https://doi.org/10.1515/cclm-2013-0223 PMid:23729625

18. Stavroulopoulos A, Porter CJ, Roe SD, Hosking DJ, Cassidy MJ. Relationship between Vitamin $\mathrm{D}$ status, parathyroid hormone levels and bone mineral density in patients with chronic kidney disease stages 3 and 4. Nephrology (Carlton). 2008;13(1):63-7. https://doi.org/10.1111/j.1440-1797.2007.00860.x PMid:18199106

19. Wang WH, Chen LW, Lee CC, Sun CY, Shyu YC, Hsu HR, et al. Association between parathyroid hormone, $25(\mathrm{OH})$ Vitamin D, and chronic kidney disease: A population-based 
study. Biomed Res Int. 2017;2017:7435657. https://doi org/10.1155/2017/7435657

PMid:28367447

20. Muntner P, Jones TM, Hyre AD, Melamed ML, Alper A, Raggi P, et al. Association of serum intact parathyroid hormone with lower estimated glomerular filtration rate. Clin J Am Soc Nephrol. 2009;4(1):186-94. https://doi.org/10.2215/cjn.03050608 PMid:19019998

21. Pala AS, Kaya E, Alagoz S, Trabulus S, Bolayirli M, Altiparmak MR, et al. Prevalence of Vitamin $D$ deficiency in patients with stage $3 / 4$ chronic kidney disease and its relation to secondary hyperparathyroidism. Turk J Nephrol. 2019;28(2):132-7.

PMid:20352364

22. Bureo JC, Arévalo JC, Antón J, Adrados G, Jiménez Morales JL,
Robles NR, et al. Prevalence of secondary hyperparathyroidism in patients with stage 3 and 4 chronic kidney disease seen in internal medicine. Endocrinol Nutr. 2015;62(7):300-5. https:// doi.org/10.1016/j.endoen.2015.08.007

PMid:26138703

23. Levin A, Bakris GL, Molitch M, Smulders M, Tian J, Williams LA, et al. Prevalence of abnormal serum Vitamin D, PTH, calcium, and phosphorus in patients with chronic kidney disease: Results of the study to evaluate early kidney disease. Kidney Int. 2007;71(1):31-8. https://doi.org/10.1038/sj.ki.5002009

PMid:17091124

24. Malawadi BN, Suma MN, Prashant V, Akila P, Anjalidevi BS, Manjunath S. Secondary hyperparathyroidism in all the stages of chronic kidney disease in Southern Indian population. Int $\mathrm{J}$ Pharm Pharm Sci. 2014;6(4):287-90. 